\title{
Kumaragara, Rakshakarma and Special Care Neonatal Unit: A Critical Review
}

\author{
Review Article
}

\section{Chris Antony ${ }^{*}$}

1. Research Officer (Ayurveda), Regional Ayurveda Research Institute, CCRAS, Jaral, Pandoh, Mandi. Himachal Pradesh, India.

\begin{abstract}
The protective rites of a newborn are an important part of neonatal care according to Ayurvedic principles. Similar to the organization of Special Care Neonatal Unit (SCNU) which is essential for reducing neonatal mortality and improving quality of life of survivors, Ayurveda advises meticulous organization of sutikagriha (the puerparial room) and kumaragara (the infant care room) along with rakshakarma (protective rites) for maintaining strict asepsis and providing a healthy environment to the mother and infant. An understanding of these protective rites and infant care room is mandatory to incorporate the Ayurvedic neonatal care into the modern neonatal care which is attempted in this paper. Relevant Ayurvedic treatises like Charaka Samhita, Susruta Samhita, Kasyapa Samhita, Ashtanga Sangraha and Ashtanga Hridaya were studied along with the guidelines by National Neonatology Forum of India for the setting up of a Special Care Neonatal Unit (SCNU). A comparison of the kumaragara and rakshakarma with Special Care Neonatal Units of modern neonatology reveals that highly recommended aseptic measures in the form of rakshas or amulets, dhupana or fumigation, vigil for graharoga or infectious diseases, etc. were followed in Ayurvedic nursing homes even before the advent of modern neonatology and construction and standard of care in a kumaragara is similar to that in an SCNU. There are a lot more principles to be adopted from Ayurveda for guiding future integrative medicine.
\end{abstract}

Key Words: Kumaragara, sutikagara, rakshakarma, protective rites, dhupana, SCNU.

\section{Introduction}

The protective rites of a newborn are an important part of neonatal care according to Ayurvedic principles. The care of the pregnant lady, care during delivery, care of puerparial woman and infant care are continuous and intricately related. Similar to the organization of Special Care Neonatal Unit (SCNU) which is essential for reducing neonatal mortality and improving quality of life of survivors, Ayurveda advises meticulous organization of sutikagara (the puerparial room) and kumaragara (the infant care room) along with rakshakarma (protective rites) for maintaining strict asepsis and providing a healthy environment to the mother and infant. Specific measures are advised for the care of the newborn which involves immediate care till pranapratyagamana (resuscitation) followed by general care throughout neonatal period and beyond. These protective rites are observed in the sutikagara (the puerparial room) and kumaragara (the infant care room).

When the process of delivery gradually shifted from homes to hospitals, sterile environments for labour

* Corresponding Author:

\section{Chris Antony}

Research Officer (Ayurveda),

Regional Ayurveda Research Institute,

CCRAS, Jaral, Pandoh, Mandi,

Himachal Pradesh, PIN-175124, India.

Email Id: chrisantony1@,gmail.com in the form of labour room and neonatal care units were established. Government of India has launched an initiative to establish SCNU's at all district hospitals. An understanding of protective rites and infant care room is mandatory to incorporate the Ayurvedic neonatal care into the modern neonatal care which is attempted in this paper.

\section{Materials and Methods}

Relevant Ayurvedic treatises like Charaka Samhita, Susruta Samhita, Ashtanga Sangraha and Ashtanga Hridaya were studied along with the guidelines by National Neonatology Forum of India for setting up of SCNU's along with previous research in the field.

\section{Results}

All treatises have recommended the establishment of sutikagara (the puerparial room) and kumaragara (the infant care room) along with rakshakarma (protective rites) for providing a healthy environment to the mother and infant. There is very little research and review in the topic presently. The following results were obtained after studying the treatises and guidelines followed by National Neonatology Forum of India.

\section{Goals of Rakshakarma and Kumaragara}

Similar to the functions of SCNU, the goals of rakshakarma and kumaragara are- 
- Care at birth including resuscitation of asphyxiated newborns.

- Care of the mother infant dyad after delivery.

- Protection from deadly infections and communicable diseases (graha and upasargaroga).

- Care of sick newborns.

\section{Sutikagara and Kumaragara}

A special room for delivery called sutikagara is mentioned to which the mother and baby are confined till sutikothana (tenth day rites after delivery). After this, kumaragara or special room for baby and mother is advised. In olden times, delivery was conducted by experienced Prasuti (obstetric) women who visited houses to conduct deliveries. Only complications were managed by Salyatantra (Surgery) experts like for obstructed labour. Elaborate descriptions of kumaragara are given which have to be built according to principles of Vastu (the Indian science of architecture). The establishment of kumaragara is mentioned by Acharya Charaka and Acharya Vagbhata-I as follows (Table 1):

\section{Table 1: Description of Kumaragara by Charaka (1) and Vagbhata-I (2)}

\begin{tabular}{|c|c|c|}
\hline Charaka & Vagbhata-I & Description \\
\hline $\begin{array}{l}\text { Vasthuvidyaakusala: } \\
\text { prasastham ramyam }\end{array}$ & $\begin{array}{l}\text { Prasastha } \\
\text { vaasthusaranam }\end{array}$ & $\begin{array}{l}\text { The kumaragara should be built according to Vastu principles by an } \\
\text { expert architect in the best possible manner for proper lighting and } \\
\text { ventilation, asepsis and air pressure control. It should be beautiful. }\end{array}$ \\
\hline Atamskam & $\begin{array}{l}\text { Atamaskam cha } \\
\text { sasyate }\end{array}$ & $\begin{array}{l}\text { Not dark. Well lighted rooms allowing entry of sunlight for UV } \\
\text { disinfection and prevention of fungal growth. }\end{array}$ \\
\hline $\begin{array}{l}\text { Nirvaatam pravaata } \\
\text { ekadesam }\end{array}$ & $\begin{array}{l}\text { Nirvaatam cha } \\
\text { pravaatam cha (Indu- } \\
\text { Nirvatam ekadeshe, } \\
\text { ekadeshe pravatam) }\end{array}$ & $\begin{array}{l}\text { Free from droughts of air/strong winds but well ventilated. Charaka } \\
\text { and Indu advise only one corridor. }\end{array}$ \\
\hline Dridam & & Made of strong material/ sturdy. \\
\hline $\begin{array}{l}\text { Apagata swapada } \\
\text { pashu damshtri } \\
\text { mooshika pathanga }\end{array}$ & $\begin{array}{l}\text { Nirmatkuna aakhu } \\
\text { masakam }\end{array}$ & $\begin{array}{l}\text { It should give protection from wild animals, dogs, cattle, fanged } \\
\text { creatures like snakes, rodents, insects like mites, mosquitoes, flies, } \\
\text { moths, etc. }\end{array}$ \\
\hline $\begin{array}{l}\text { Suvibhakta salila } \\
\text { ulookhala mutra } \\
\text { varcha-staana } \\
\text { Snaanabhumi } \\
\text { mahaanasam }\end{array}$ & - & $\begin{array}{l}\text { It should have well separated areas for water storage and washing, } \\
\text { medicine preparation, baby care, toilets, bath areas of newborns, and } \\
\text { kitchen. }\end{array}$ \\
\hline $\begin{array}{l}\text { Ritu-sukham } \\
\text { yatharthu sayana } \\
\text { aasana } \\
\text { aastharana } \\
\text { sampannam } \\
\text { kuryaat }\end{array}$ & - & $\begin{array}{l}\text { It should be conditioned according to the season and comfortable to } \\
\text { live in all seasons, furnished with proper and ample supply of } \\
\text { seatings, beddings, blankets, spreads, etc. }\end{array}$ \\
\hline \multirow{2}{*}{$\begin{array}{l}\text { Tatha suvihita } \\
\text { rakshavidhana } \\
\text { balihoma } \\
\text { prayaschittam }\end{array}$} & - & $\begin{array}{l}\text { It should be equipped with facilities for proper conduction of } \\
\text { protective rites, worship/offerings, oblations, atonements, etc. }\end{array}$ \\
\hline & Sajjopakaranam & $\begin{array}{l}\text { Provided with functional equipments ready for use at any time. } \\
\text { These include sastras or sharp instruments, supplies for immediate } \\
\text { care of newborn like sterile cotton, honey, ghee, rock-salt, } \\
\text { ardhadhara sastra (scalpel) for cutting of umbilical cord, utensils of } \\
\text { different sizes, linens, etc. and medicines for emergency use and } \\
\text { fumigation. }\end{array}$ \\
\hline Suchi & Suchi & Clean. \\
\hline $\begin{array}{l}\text { Vriddha-vaidya } \\
\text { anurakta } \\
\text { sampoornam }\end{array}$ & $\begin{array}{l}\text { Vriddha stree vaidya } \\
\text { sevitam }\end{array}$ & $\begin{array}{l}\text { The service of experienced physicians/ pediatricians and elderly/ } \\
\text { experienced nurses preferably females who are passionate in the } \\
\text { care of newborns should be available. }\end{array}$ \\
\hline
\end{tabular}

Trained nurses/ personnel in kumaragara (3)

Personnel is the most important part of kumaragara. Females who are proficient in nursing care of newborns should engage day and night for first 10-12 days. Close friends and relatives and well-wishers should keep them happy taking care of mother and child's nutrition. Suthika paricharya (care of the puerparial woman) parallel to neonatal care should be followed to prevent infections and promote lactation.

\section{Immediate protective rites during and after birth}

The protective rites of newborn immediately after delivery include pranapratyagamana (resuscitation), ulbavishodhana (clearing the vernix caseosa), balataila parisheka (smearing of medicated 
oil), karnayor moole asmanor ghattanam (striking stones near ears for arousal), mukha-kanta sodhana (clearing the mouth and throat), garbhodaka vamana (emesis of amniotic fluid), nabhinadi-chedana (cutting of the umbilical cord), jatakarma (birth rites) prashana (prelacteal feeds), and other rakshakarma (protective rites) that follow (4). Bala taila is needed for smearing the newborn after clearing the vernix with rock salt and ghee. Clearing the mouth and throat requires sterile cotton. Cold and lukewarm water as per season is needed for thermal stimulation. Emesis of amniotic fluid is stimulated using a mixture of ghee and honey which is given as an electuary. This can also be done using mild suction with mucous suction apparatus. Garbhodaka vamana causes urakanta visuddhi (clarity of chest and throat), laghava (lightness) and abhilasha (eagerness/appetite) (5). The importance of garbhodaka vamana (emesis of amniotic fluid) and its impact on prevention of acidosis in newborns should be subject to further study. Cutting of the umbilical cord is done with tikshna sastra (scalpel made of gold/silver/iron) above 4 angulas (finger measure) followed by smearing of kushta taila on the umbilical stump (6). As part of jatakarma or birth rites, madhu ghrita prashana (prelacteal feed made from honey and ghee), stanapana (breastfeeding) and udakakumbha sthapana (placing of pot filled with water to maintain humidity) are done (7). Srothra sringataka (ears and vital point at the joining of ears, nose and mouth) is smeared with cloth piece smeared with oil (8).

After immediate neonatal care, protective rites are followed for 10-12 days continuously in the purerparial care room and after suthikothana (tenth day rites/ bathing of puerparial woman) the mother and baby are transferred to a kumaragara with all amenities for newborn care equipped in it.

\section{General protective measures in kumaragara}

Charaka has elaborately described the protection of the child care room by disinfection techniques and restriction of entry (9). Twigs of Adani, Khadira (Acacia catechu Willd.), Karkandhu (Zizyphus nummularia W. \& A.), Peelu (Salvadora persica Linn.), Parushaka (Grewia asiatica Linn.) are spread around the nursery for disinfection and to keep away insects and rodents. Vagbhata-I mentions Adari, Vidari (Pueraria tuberosa Willd.) and Nimba (Azadirachta indica A. Juss) also for fanning the child and spreading around sutikagara. Indu comments Adari as Kakahantali, Thoya, or Khadiravalli (10). Susruta has advised spreading of Sarshapa (Brassica juncea (L.) Czern), Atasi (Linum usitatissimum Linn.), Tila (Sesamum indicum L.), etc. inside sutikagara (11). Swasthi karma or shantikarma in the form of balihoma-karma (sacrifices) by brahmanas twice a day is also advised till naming ceremony on $10^{\text {th }}$ day. Indu mentions utility of balikarma as 'bhootopaharam' or warding off of infective agents. Vagbhata-I also mentions the reciting of mantras like mayuri, mahamayuri and aryaratnaketudharini twice a day in the sutikagara. Indu comments it on as laghumayuri or saptasathi vidya and mahamayuri or chathu:sahasri vidya mantras. (12)

To restrict entry of visitors, Charaka has advised musala (pestle or club) to be placed obliquely at the entrance. He also advises Vacha (Acorus calamus Linn.), Kushta (Saussuria lappa C. B. Clarke), Kshoumaka (Linum ussitassimum Linn.), Hingu (Ferula narthex), Sarshapa (Brassica campestris (L.) Czern), Atasi (Linum ussitassimum Linn.), Lasuna (Allium sativum Linn.), Kana (Piper longum Linn.) and similar protective drugs to be tied in packets and hanged on upper beam of entrance door. These should also be tied around the neck of mother and baby. These drugs should be spread around water pots, plates, cooking vessels, bed steads, etc. and about both the entrances.

For prevention of hypothermia in newborn continuous fire is advised (13). For this firewood of Tinduka (Diospyros peregrina) and 'kana kantaka tinduka indhana' should be stocked for continuous provision of fuel. (14) Indu comments kana as khandatandula (broken rice) and kantaka as tandulakshodana churnam (rice husk). (15) Throughout day and night vigil is to be kept by loving and friendly females over the mother and infant and fire.

\section{Baby care}

Baby should be wrapped well in clean kshouma-vastra (linen cloth) and placed on bed covered with kshouma-vastra (linen cloth). (16) The baby should be laid with head towards the east on soft cloths and beds with a pot of water placed near head side and near both sides of the door (17). Head should be daily anointed with oil-soaked tampon. Fanning should be done with branches of Peelu (Salvadora persica Linn.), Badari (Ziziphus mauritiana Lamk.), Nimba (Azadirachta indica A. Juss) and Parushaka (Grewia asiatica Linn.). Dhoopana (fumigation) with rakshoghna drugs should be done daily. The newborn should be cared for with strict aseptic precautions as if like caring a wounded- explained in vranithopasaneeya chapter (18).

\section{Handling of baby}

The baby should be handled or held in a gentle and comfortable manner. Babies should not be beaten or battered. Battered child develops physical deformities due to fractures and also mental disorders later. The baby should not be roused suddenly as it can frighten the baby and cause shock. The baby should not be taken or transferred suddenly nor should be raised or held up suddenly. This may cause vatadi vighata (vitiation of doshas especially vata). Shaken baby syndrome can also develop. The baby should not be made to sit before fifth month (upaveshana samskara during fifth month). Early sitting can cause kaubjya or hump-back/kyphosis. Baby should be kept happy, only then he grows and remains disease-free. (19). Vagbhata-I mentions that by waking up the baby from sleep and putting him up in air, shock or tremors and vega-rodha (suppression of urges) can happen (20). 
Forbidding fearful measures to make the child obey

Further it is advised not to frighten the child even if not obeying or inconsolable as it can cause shock and graharogas. Baby should also be protected from clothes falling on face, from being handled by persons other than close ones and also from langhana (hunger, thirst, sun, wind, etc.) (21). Baby uncared for does not grow well or gain weight. This is a general advice for not just neonates but for all children of all ages. Charaka also advises that even when the child cries and not takes food or disobeys, the baby should not be frightened by mentioning the names of rakshasa, pisacha, pootana, etc. (22)

\section{Bathing of the neonate}

The baby is advised to be bathed after resuscitation and thereafter daily in water boiled with Ksheerivriksha (barks of latex exuding trees of ficus species), Sarva Gandha (all fragrant drugs), Kapitha Pathra Kashaya (decoction of leaves of Feronia limonia Linn.) or any antiseptic drugs available as per season. The water should be lukewarm (23).

\section{Dressing and beddings of baby}

Clothes washed, clean, ironed, and without folds, soft dressings, covers and beddings should be used for newborns and should be fumigated by rakshoghna drugs. (24) The beddings, blankets, bedsheets, etc. for newborn should be soft, light in weight, clean and of pleasant smell. Clothings and diapers soiled with urine and faeces or wet with sweat and infected or infested with microbes and insects should be removed. There should be ample supply of clothings. Disposables are preferred. If not available/ affordable reuse after washing well, disinfecting, drying and fumigating is advised (25).

\section{Dhoopana (fumigation)}

Fumigation is an important mode of disinfection (26). Vagbhata-I advises 'vranoktaishcha guggulwadibhir dhoopam kurvita' or fumigation with Guggulu (Commiphora mukul) etc mentioned for fumigation of ulcers. (27) Indu comments that it is dhupa mentioned in Sutrasthana sastrakarmavidhana -Guggulu (Commiphora mukul Eng1.), Agaru (Aquillaria agallocha (Lour.) Roxb.), Sarjarasa (Vateria indica L.), Vacha (Acorus calamus Linn.), Gourasarshapa (Sinapis alba L.). For fumigation, feathers of dead crow with Trivrit (Operculina turpethum (L.) S. Manso) or with Vacha (Acorus calamus Linn.), ghee, Kushta (Sausssuria lappa Clarke), Sriveshta (Pinus roxburghii Sarg.), Sarshapa (Brassica campestris (L.) Czern), etc are advised on daily basis. (28) Charaka advises fumigation of clothes and beddings also with Yava (barley), Sarshapa, Atasi, Hingu (Ferula narthex Boiss), Guggulu, Vacha, Choraka (Angelica glauca Edgew.), Vayastha (Bacopa monnieri (L.)), Golomi (type of Vacha), Jatila (Nardostachys jatamamsi DC.), Palamkasha (type of Guggulu), Asoka (Saraka indica Sensu Bedd.), Rohini
(Picrorhiza kurroa Royle), Sarpanirmokta (slough of snake) mixed with ghee and burnt for fumigation of clothes etc. (29).

\section{Raksha or Amulets}

Vagbhata-I mentions the tying of potalis (packets) of Hingu, Vacha, Turushkara, Rakshoghna (Sarshapa), etc. on top wooden plank of the door. These rakshoghna (protective) drugs are advised for fumigation and for tying on hands, legs, head and neck of the child and mother. The tying of Aryaparna sabari vidhya and Arya aparajita vidya are also mentioned as rakshas (amulets). Indu comments on these as mantras written on bhurjapatra (birch leaf) using Gorochana (Ox gall) and tied on head and neck as amulets. (30)

Gemstones and horns taken from living horned animals should be tied on the newborns limbs as jewellery and for protection. Similarly, medicinal herbs Aindryadi ten drugs or Jeevaka (Malaxis acuminta D. Don) and Rishabhaka (Microstylis muscifera Ridley) are advised to be worn on body- neck, hands, head, etc. All drugs used by Atharvavedavit brahmanas are also advised for use in kumaragara. (31) Vacha (Acorus calamus Linn.) alone also can be used for rakshoghna (protective) purposes, and is advised to be worn on hands, neck, head, etc. daily all the time, and is said to promote longevity, intellect, memory, health, and give protection from rakshas and uparakshas (infective agents). (32)

\section{Protection from physical harms}

The baby should be protected from winds, sun, lightning/electric shocks, bright light, trees and creepers and climbers and should not be left in unclean or dirty places, or in the air (in hanging beds) or in places without roofs, or in irregular/uneven grounds, rain, dust and water. The baby should not be left alone in empty rooms or houses, low grounds or puddles and should be protected from eclipses or shadows of planets, and especially from severe graha or upasarga rogas (infectious and communicable diseases) etc. (33)

\section{$6^{\text {th }}$ day rites}

Rakshakarma and balikriya (sacrifices and prayers) are advised especially on the sixth day and relatives are advised to remain watchful and keep the mother and child happy. (34) Usually, umbilical cord falls on $5^{\text {th }}$ day. Caution is advised here to look out for signs of sepsis/ tetanus due to sepsis from improper cutting of cord (latent period of tetanus neonatorum being 5-15 days). Tetanus and sepsis are caused due to lack of aseptic care at birth. Nowadays prevention of tetanus begins before birth with tetanus toxoid injections in mother to prevent neonatal tetanus.

\section{$1^{\text {th }}$ day rites (Suthikothana, namakarana samskara and Ayupariksha) (35)}

On completion of tenth day or on twelfth day, as per rituals of one's family/clan, suthikothana samskara or snanotsava (bathing the puerparial woman) and namakarana samskara (naming ceremony) of newborn should be done. Naming is done by father and 
may be done also on $100^{\text {th }}$ day or on completion of one year. Naming gives identity of the newborn in the society and is important in personality development. As a ritual, it is conducted after the child is bathed and adorned with Manohwa (realgar), Haritala (orpiment), Rochana (ox gall), Agaru (Aquilaria agallocha Roxb.), Chandana (Santalum album L.) on body and presented before relatives and friends. Two names are givennakshatra-devatayukta (related to one's birth star and its lord), baandhava (one which is common among the relatives), usually a grandparent's name.

Following the naming ceremony, ayu-pareeksha (36) or examination of the baby is done as per treatises explaining normal features of newborns. The baby is to be placed in north or east direction during examination in a well-lighted room. Examination of newborn is done for assesment of anomalies/ dysmorphism and longevity (ayusha: pramanajnaana heto:). Charaka has given elaborate description of normal features of each body part. They should be prakritisampannam or normal and denotes a child with long life (deerghayu). Any deviation denotes lesser life span and is not desirable (anishta).

\section{Sutikagara nishkramana vidhi (Taking the child out of sutikagara) (37)}

Till 4 months confinement to kumaragara for most of the time is advised. The baby should be adorned and taken out after prayers in the fourth month to temples or places of worship. After the neonatal period, general care including prashana (electuaries) is continued to ensure the full potential growth and development of the baby. Vagbhata-I has advised to rear the child predominantly at home for one year and not to show bright lights, sun, fire or any brilliant objects. (38)

All samskaras or ceremonies which are important in physical, mental, social and spiritual growth of humans are advised by Ayurveda like, upaveshana (sitting), annaprashana (first feeding of cereals), upanayana (rites of passage), vivaha (marriage), etc.

\section{Kreedabhumi (Play place) and Kreedanaka (Toys)}

As per Vagbhata-I the play place of the child should be even and free from sharp instruments/articles, rocks and pebbles and should be disinfected with decoctions of Vidanga (Embelia ribes Burm F.), Ushna (Piper nigrum L.), Kana (Piper longum L.), etc. or with neem decoction. Toys should be made of gum material, making sounds and with figures on it. It should not be frightening but be pleasant and large, without sharp ends, of the shapes of cow, horse, fruits or any other pleasant shapes. (39). Charaka explains further that toys should be not heavy and not of the size which the child can put inside the mouth and produce choking and death. (40)

\section{Kumara-adhara (Caretaker of the child)}

Vagbhata-I has advised to appoint a caretaker for the child. The time is not mentioned whether for newborn or for infant or beyond but the qualities of the caretaker is well explained. The person appointed to look after the baby should be of high morals and should not be obese and greedy. He should be knowing the desires of the child easily. Immoral and gluttonous caretakers can make the child sick by overfeeding. (41)

\section{Swasthravritta (Protection of health)}

Charaka advises to follow swasthavritta during health to preserve health in children. All foods and regimen opposite to one's desha (region), kala (climate), atmaguna (physical and mental constitution) is to be followed. For example, hot food and regimen in cold regions and climate; kapha alleviating food and regimen in an excessively kapha predominant constitution. Slowly all asatmya (incompatible) food and regimen which is ahita or unfavourable for health should be relinquished and hita upachara (favourable food and regimen) should be adopted in a child's life. Thus, bala-varna-sareera-ayus sampat or excellence of strength, complexion, body and life span can be obtained. Till achieving youth, child should be brought up in this way for attaining skills and performing religious duties. (42). Texts also mention protective ghees like Brahmyadi and Saraswata ghritas, avalehas (lickables) and prashanas (electuaries) etc. for prevention of diseases in the child and for ensuring unimpaired growth and intellect. (43)

Charaka extols the advantages of childcare saying that just like a city protected by valorous armed men is invincible to enemies, the body of a child who is taken care of following the yathokta vidhis or aforementioned advices is protected from all kinds of grahas (infections). (44)

\section{Guidelines for setting up of Special Care Neonatal Unit as per National Neonatology Forum of India} (45)

The establishment of a Special Care Neonatal Unit (SCNU) is similar to that of a kumaragara but caters a larger population in a hospital setting. There are specific guidelines for providing physical facilities of SCNU which include the following parameters-space, location, design, ventilation, lighting, environmental temperature and humidity, acoustic characteristics, electrical outlets, etc.

\section{Space}

Space should be according to the expected population to be served. There should be special care for 6-8 high risk infants in a unit having 2000 deliveries per year. Each infant should have a space of $100 \mathrm{sq}$. $\mathrm{ft}$. Additional space for extramural babies should also be provided in referral units.

\section{Location}

Neonatal unit should be close to labour room and obstetric operation theatre for transfer of sick infants with an elevator close by for transfer of extramural babies.

\section{Design}

The SCNU should be designed in a square space /single corridor based rectangular unit. Split unit 
on either side of corridor is avoided to prevent transfer of infections. It should facilitate constant surveillance and minimal walking distance for staff.

\section{Nursery design}

There should be separate baby care area, mother's area, examination area, handwashing \& gowning room, handwashing stations, area for preparation of IV fluids, nurses' station, staff rooms, clean utility and soiled utility holding rooms, growing nursery, etc.

Baby care area should include areas and rooms for intramural babies, step down nursery, area for extramural babies and examination area. Infected infants should be isolated in a septic nursery room away from SCNU.

Mother's area, nurses' station and charting areas should be provided with washable glazed floors and walls and windows with two layers of panes to ensure heat and sound insulation. Mother's area is for breast feeding and expression of breast milk.

Examination area should be a small comfortable room with examination table, comfortable seating, sufficient light \& warmth. Baby should be assessed before admission to nursery, cleaned and provided with nursery garments.

Handwashing and gowning room should be at the entrance with abundant space, self-closing doors, positive air pressure to prevent corridor air entering the SCNU. Street shoes should be changed to nursery slippers. Hand free elbow operated hand washing sink with liquid soap dispenser should be provided. Sink should be made of porcelain / stainless steel which is easily washable. Disposable napkins or hot air dryer for hand drying should be provided.

Handwashing stations with sinks within 20 feet of every newborn bed, antiseptic solution for disinfection of hands and disposable paper napkins for drying hand should be provided.

Area for preparation of IV fluids should have separate areas for parenteral nutritional formulations, IV fluids, enteral feeds and medications. Boiling and autoclaving facilities should be available next to this area.

Staff rooms to meet professional, administrative and personal needs of resident staff on duty should be provided within the unit. Nurses station should be located in a central area where all babies can be observed.

Clean utility and soiled utility holding rooms are mandatory with negative air pressure maintained in soiled utility rooms.

Growing nursery-A separate bay for transitional care of high-risk babies by their mothers before discharge from hospital, to educate mothers in child craft activities and promoting practice of exclusive breast feeding, accurate weighing, etc. should be present.

\section{Ventilation}

Effective air ventilation of nursery is essential to reduce nosocomial infections. Exhaust fan in reverse direction near ceiling for input of fresh uncontaminated air and another exhaust fan in conventional manner near floor are recommended for maintaining positive air pressure in the nursery.

\section{Lighting}

SCNU should be well illuminated and painted white or off-white to permit early detection of jaundice and cyanosis. Cool white flourescent tubes / LED should be used. Light should be dimmed at night to simulate day-night pattern to promote hormonal surge and growth of babies.

\section{Environmental temperature and humidity}

Temperature should be maintained between 26-28 degree celsius to minimise effect of thermal stress on babies. Humidity levels is to be raised for preterm babies in incubators to reduce insensible water loss but this has increased risk of infections.

\section{Acoustic characteristics}

Sound intensity in nursery should not exceed 75 decibels to protect hearing of infants and personnel. Effective sound proofing of ceilings, walls, doors and floors is desirable.

\section{Handling and social contacts}

Gentle handling of babies is advised. Parents are allowed unrestricted entry into nursery.

\section{Communication system}

Intercom system to call for help and additional personnel in emergencies and direct line external telephone for parent contact are mandatory. Mobile phones are not to be used with in nursery as electronic equipments function.

\section{Electrical outlets}

8-12 electrical points at the height of 4-5 feets for each bed and uninterrupted servo-stabilized power supply are mandatory.

\section{Personnel in SCNU}

Highest priority of a nursery is sufficient number of adequately trained nurses. At least one trained nurse to provide coverage to 4 babies in SCNU is advised by National Neonatology Forum of India. Nurses should be well trained in neonatal nursing and maintenance of electronic equipments in SCNU. They must participate in monthly perinatal morbidity and mortality meetings. Unit should have an independent senior resident doctor and one junior resident doctor for every 8 babies, a lab technician, a biomedical technician for smooth functioning of equipments and a respiratory therapist to monitor ventilatory settings, tracheal suctioning and chest physiotherapy.

\section{Equipments in SCNU}

The following equipments are minimum required in an SCNU

- Resuscitation equipments- Emergency tray- in each infant care room of SCNU containing -Ambu bag and 
mask, laryngoscope, tracheal tubes of different sizes, sterile suction catheters, oral mucous suction traps \&emergency drugs.

- Bag and mask resuscitator- Self inflating silicon rubber bag of $250-500 \mathrm{ml}$ capacity ideal for resuscitation of newborn - Ambu bags or Laerdal bags.

- Oxygen and suction facilities- centralised sources of oxygen and compressed air and suction outlet consoles affixed on walls which are ideal with variable concentrations of oxygen and compressed air that can be used to obtain oxygen concentrations between $25-100 \%$.

- Suction catheter- De lee trap, suction catheters (ideal for use at birth), or centralized suction, venturi suction and electrical suction which are ideal for hospitals.

- Catheters, syringes and needles-Nasogastric feeding tubes, umbilical vein catheters, small vein infusion sets, medi-caths, exchange transfusion sets, etc.

- Resuscitation trolley- equipped with radiant warmer, timer, electrical suction, observation light and manual facilities, inbuilt pulse oximeter to monitor heart rate and oxygen saturation.

- Feeding equipment and autoclave-Glass or stainlesssteel bowls of adequate size- $120 \mathrm{ml}$ for collection of expressed breast milk, mixing and preparation of formulas, etc., hot air autoclaving oven used for sterilizing the equipments, etc.

- Laminar flow system-useful for safe and aseptic formulation and mixing of drugs, parenteral fluids and nutrients.

- Weighing machine- A sensitive beam type weighing scale with precision of $+/-10 \mathrm{~g}$ is useful in the nursery. Electronic weighing machines are desirable.

- Bassinets- It is desirable to use plexi-glass bassinets which are easily cleaned and equipped with locker and head-tilting mechanism.

- Incubators- provide ideal microenvironment for highrisk babies. 1/3 of nursery bed should be incubators. Incubators are required for isolation, maintenance of thermoneutral temperature, desired humidity, administration of oxygen, to nurse ELBW babies below $1000 \mathrm{~g}$ stable babies, etc. Sensory stimuli like light, sound etc. should be kept to barest minimum. Water in humidity tank should be changed daily and 1-2 ml of glacial acetic acid / vinegar should be added to prevent colonization

- Radiant heat warmer/ open care system- to keep babies warm during procedures. After stabilization in an open care system, the baby should be covered with clothes/ thin polythene sheet to reduce evaporative fluid losses. Application of sterile liquid paraffin or non-irritating oil on the skin is associated with reduced evaporative losses from skin.

- Thermometers- Low reading (30-40 degree C) rectal thermometer, electronic or tele-thermometers with acoustic and visual alarms.

- Oxygen concentrator- to deliver various concentrations of oxygen.

- Oxygen head box/oxihood- Square shaped box made up of transparent plastic / perspex which can enclose the head of the infant for administration of higher concentration of oxygen.

- Oxygen analyser- monitors ambient oxygen concentration to protect infant against oxygen toxicity.

- Perspex heat shield- to reduce heat loss by radiation and evaporation. Sick infants with respiratory distress syndrome, nursed naked in incubator should be enclosed in perspex heat shield.

- Heart rate monitor-Ideal to monitor high risk infants during prolonged procedures.

- Respiratory rate and apnoea monitor- Electrode fixed on chest wall. When infant stops breathing emits a beep and displays red warning signal.

- BP monitor.

- Multichannel vital sign monitor- Displays and records all vital signs- heart rate, respiratory rate, apnoea alarm, invasive and non- invasive blood pressure, pulse oximetry, etc.

- Pulse oximeter-for continuous monitoring of hemoglobin saturated with oxygen. To safeguard against risk of hypoxia and retinopathy of prematurity, it is recommended that oxygen concentration is $95 \%$.

- Phototherapy unit- for treatment of hyperbilirubinemia. Latest fiberoptic bili-blankets may also be used.

- Bilirubin analyser and transcutaneous bilirubinometer.

- Infusion pump-For relatively small quantities of fluids infused as minor errors prove lethal in LBW babies. Syringe based micropump is ideal for administration of drugs.

- Gamma radiation for sterilization.

- Liberal supply of disposables crucial for reduction of nosocomial infections.

\section{Discussion}

A comparison of the kumaragara and rakshakarma with Special Care Neonatal Units of modern neonatology reveals that highly recommended aseptic measures were followed in Ayurvedic nursing homes even before the advent of modern neonatology. The care of the newborn and the mother was not restricted to first 3-5 days even in normal delivery but upto 10 days and even beyond in a special care room called sutikagara/kumaragara. Restricted entry to visitors and service of experienced personnel were ensured to keep mother and child happy and also look for danger signs. Medicated oils and water to prevent hypothermia and infections, for cord care and healing of umbilical wounds/infections, prashanas to improve immunity and intellect and dhupana or fumigation to ward off infections, puerparial care to mother to ensure proper recovery of mother and ensure proper lactation, etc. are elaborately described in the treatises. Management of newborns like a vrana rogi (wounded) highlights the strict aseptic principles advised by Ayurveda. Prashanas can replace probiotics which are advised in modern neonatal care which has the added benefits of reducing oxidative stress, hyperbilirubinemia, hemolytic disease and improving 
neurological outcomes. Garbhodaka vamana (emesis of amniotic fluid) should be studied for its effects on acidosis and oxidative stress. Medicated oils can be substituted for paraffin to prevent water loss and hypothermia and aid in faster recovery. Vastu principles can be followed in designing SCNUs. Further research is needed for incorporating the advices of Ayurvedic neonatal care in NICU's and SCNU's.

\section{Conclusion}

A comparative study of kumaragara (special room for newborn), rakshakarma (protective rites) and Special Care Neonatal Unit (SCNU) has revealed similar standards of care of newborn in both kumaragara and SCNU. There are a lot more principles to be adopted from Ayurveda for guiding future integrative medicine.

\section{Acknowledgements}

I am grateful to Dr Rajesh Sannd, Assistant Director and colleagues of Regional Ayurveda Research Institute Mandi Himachal Pradesh for their constant encouragement and scientific advice.

\section{Reference}

1. Sharma RK, Dash B. Agnivesa's Charaka Samhita Text with English translation and critical exposition based on Chakrapani Datta's Ayurveda Deepika Volume II Nidana to Indriya Sthana. Reprint 2019. Varanasi; Chaukhambha Sanskrit Series; 2019. $512-513 p$.

2. Thakkar VJ. Ashtanga Sangraha of Vagbhata with commentary of Indu by CCRAS New Delhi. Azadpur; Mayur Press; 1988. 7p.

3. Sharma RK, Dash B. Agnivesa's Charaka Samhita Text with English translation and critical exposition based on Chakrapani Datta's Ayurveda Deepika Volume II Nidana to Indriya Sthana. Reprint 2019. Varanasi; Chaukhambha Sanskrit Series; 2019. $512-513 p$.

4. Thakkar VJ. Ashtanga Sangraha of Vagbhata with commentary of Indu by CCRAS New Delhi. Azadpur; Mayur Press; 1988. 1-5p.

5. Thakkar VJ. Ashtanga Sangraha of Vagbhata with commentary of Indu by CCRAS New Delhi. Azadpur; Mayur Press; 1988. 3p.

6. Thakkar VJ. Ashtanga Sangraha of Vagbhata with commentary of Indu by CCRAS New Delhi. Azadpur; Mayur Press; 1988. 2p.

7. Sharma RK, Dash B. Agnivesa's Charaka Samhita Text with English translation and critical exposition based on Chakrapani Datta's Ayurveda Deepika Volume II Nidana to Indriya Sthana. Reprint 2019. Varanasi; Chaukhambha Sanskrit Series; 2019. 500 p.

8. Thakkar VJ. Ashtanga Sangraha of Vagbhata with commentary of Indu by CCRAS New Delhi. Azadpur; Mayur Press; 1988. 4p.

9. Sharma RK, Dash B. Agnivesa's Charaka Samhita Text with English translation and critical exposition based on Chakrapani Datta's Ayurveda Deepika
Volume II Nidana to Indriya Sthana. Reprint 2019. Varanasi; Chaukhambha Sanskrit Series; 2019. 500-501p.

10. Thakkar VJ. Ashtanga Sangraha of Vagbhata with commentary of Indu by CCRAS New Delhi. Azadpur; Mayur Press; 1988. 4p.

11. Narayan-Ram A. Susruta Samhita Moolamatra Kavyateertha commentary. Mumbai ; Satyabhamabai Panduranga-Nirnayasagar Press; 1945, 430p.

12. Thakkar VJ. Ashtanga Sangraha of Vagbhata with commentary of Indu by CCRAS New Delhi. Azadpur; Mayur Press; 1988. 4p.

13. Narayan-Ram A. Susruta Samhita Moolamatra Kavyateertha commentary. Mumbai ; Satyabhamabai Panduranga-Nirnayasagar Press; 1945, 430p.

14. Sharma RK, Dash B. Agnivesa's Charaka Samhita Text with English translation and critical exposition based on Chakrapani Datta's Ayurveda Deepika Volume II Nidana to Indriya Sthana. Reprint 2019. Varanasi; Chaukhambha Sanskrit Series; 2019. 500-501p.

15. Thakkar VJ. Ashtanga Sangraha of Vagbhata with commentary of Indu by CCRAS New Delhi. Azadpur; Mayur Press; 1988. 4-5p.

16. Narayan-Ram A. Susruta Samhita Moolamatra Kavyateertha commentary. Mumbai; Satyabhamabai Panduranga-Nirnayasagar Press; $1945,430 p$.

17. Thakkar VJ. Ashtanga Sangraha of Vagbhata with commentary of Indu by CCRAS New Delhi. Azadpur; Mayur Press; 1988. 4p.

18. Narayan-Ram A. Susruta Samhita Moolamatra Kavyateertha commentary. Mumbai ; Satyabhamabai Panduranga-Nirnayasagar Press; 1945, 430p.

19. Narayan-Ram A. Susruta Samhita Moolamatra Kavyateertha commentary. Mumbai; Satyabhamabai Panduranga-Nirnayasagar Press; $1945,434 p$.

20. Thakkar VJ. Ashtanga Sangraha of Vagbhata with commentary of Indu by CCRAS New Delhi. Azadpur; Mayur Press; 1988. 7p.

21. Thakkar VJ. Ashtanga Sangraha of Vagbhata with commentary of Indu by CCRAS New Delhi. Azadpur; Mayur Press; 1988. 11p

22. Sharma RK, Dash B. Agnivesa’s Charaka Samhita Text with English translation and critical exposition based on Chakrapani Datta's Ayurveda Deepika Volume II Nidana to Indriya Sthana. Reprint 2019. Varanasi; Chaukhambha Sanskrit Series; 2019. $514 \mathrm{p}$.

23. Thakkar VJ. Ashtanga Sangraha of Vagbhata with commentary of Indu by CCRAS New Delhi. Azadpur; Mayur Press; 1988. 2p

24. Thakkar VJ. Ashtanga Sangraha of Vagbhata with commentary of Indu by CCRAS New Delhi. Azadpur; Mayur Press; 1988. 7p

25. Sharma RK, Dash B. Agnivesa's Charaka Samhita Text with English translation and critical exposition based on Chakrapani Datta's Ayurveda Deepika 
Volume II Nidana to Indriya Sthana. Reprint 2019.

Varanasi; Chaukhambha Sanskrit Series; 2019. $513 p$.

26. Narayan-Ram A. Susruta Samhita Moolamatra Kavyateertha commentary. Mumbai; Satyabhamabai Panduranga-Nirnayasagar Press; 1945, 430p.

27. Thakkar VJ. Ashtanga Sangraha of Vagbhata with commentary of Indu by CCRAS New Delhi. Azadpur; Mayur Press; 1988. 4p

28. Thakkar VJ. Ashtanga Sangraha of Vagbhata with commentary of Indu by CCRAS New Delhi. Azadpur; Mayur Press; 1988. 7p.

29. Thakkar VJ. Ashtanga Sangraha of Vagbhata with commentary of Indu by CCRAS New Delhi. Azadpur; Mayur Press; 1988. 4-5p.

30. Thakkar VJ. Ashtanga Sangraha of Vagbhata with commentary of Indu by CCRAS New Delhi. Azadpur; Mayur Press; 1988. 4-5p.

31. Sharma RK, Dash B. Agnivesa's Charaka Samhita Text with English translation and critical exposition based on Chakrapani Datta's Ayurveda Deepika Volume II Nidana to Indriya Sthana. Reprint 2019., Varanasi; Chaukhambha Sanskrit Series; 2019. 513-514p.

32. Thakkar VJ. Ashtanga Sangraha of Vagbhata with commentary of Indu by CCRAS New Delhi. Azadpur; Mayur Press; 1988. 8p.

33. Narayan-Ram A. Susruta Samhita Moolamatra Kavyateertha commentary. Mumbai; Satyabhamabai Panduranga-Nirnayasagar Press; 1945, 434p.

34. Thakkar VJ. Ashtanga Sangraha of Vagbhata with commentary of Indu by CCRAS New Delhi. Azadpur; Mayur Press; 1988. 6p.

35. Thakkar VJ. Ashtanga Sangraha of Vagbhata with commentary of Indu by CCRAS New Delhi. Azadpur; Mayur Press; 1988. 6-7p.

36. Sharma RK, Dash B. Agnivesa's Charaka Samhita Text with English translation and critical exposition based on Chakrapani Datta's Ayurveda Deepika Volume II Nidana to Indriya Sthana. Reprint 2019., Varanasi; Chaukhambha Sanskrit Series; 2019. 504-507p.

37. Thakkar VJ. Ashtanga Sangraha of Vagbhata with commentary of Indu by CCRAS New Delhi. Azadpur; Mayur Press; 1988. 8p.

38. Thakkar VJ. Ashtanga Sangraha of Vagbhata with commentary of Indu by CCRAS New Delhi. Azadpur; Mayur Press; 1988. 10p.

39. Thakkar VJ. Ashtanga Sangraha of Vagbhata with commentary of Indu by CCRAS New Delhi. Azadpur; Mayur Press; 1988. 11-12p.

40. Sharma RK, Dash B. Agnivesa's Charaka Samhita Text with English translation and critical exposition based on Chakrapani Datta's Ayurveda Deepika Volume II Nidana to Indriya Sthana. Reprint 2019., Varanasi; Chaukhambha Sanskrit Series; 2019. $514 \mathrm{p}$.

41. Thakkar VJ. Ashtanga Sangraha of Vagbhata with commentary of Indu by CCRAS New Delhi. Azadpur; Mayur Press; 1988. 11p.

42. Sharma RK, Dash B. Agnivesa's Charaka Samhita Text with English translation and critical exposition based on Chakrapani Datta's Ayurveda Deepika Volume II Nidana to Indriya Sthana. Reprint 2019., Varanasi; Chaukhambha Sanskrit Series; 2019. 514-515p.

43. Thakkar VJ. Ashtanga Sangraha of Vagbhata with commentary of Indu by CCRAS New Delhi. Azadpur; Mayur Press; 1988. 13-14p.

44. Thakkar VJ. Ashtanga Sangraha of Vagbhata with commentary of Indu by CCRAS New Delhi. Azadpur; Mayur Press; 1988. 14p.

45. Singh M. Care of the Newborn. First eBook Edition. New Delhi; CBS Publishers and Distributors Pvt. Ltd. through Kindle Store. 2018. 66-122p. 